\title{
Enlightenment of Occupation Education in Colleges to Educational Transformation in NCO Academies
}

\author{
Minghai $\mathrm{Fu}^{1}$, Yanhui Zhao ${ }^{2}$ \\ ${ }^{1)}$ Bengbu Automobile NCO Academy, Bengbu, Anhui, China (fufuminghai@sina.com) \\ ${ }^{2)}$ Bengbu Automobile NCO Academy, Bengbu, Anhui, China (zhaoyanhui2005@sina.com)
}

Abstract - To construct the vocational education characteristic personnel training pattern is the key to educational transformation in NCO academies. The actual force teaching evaluation system is to improve the students' professional ability standard; teachers should be based on the integration, "quotation" and "outside" to develop and optimize the "double teacher type" of teachers. Practice teaching base is the quality and characteristics of sergeant education guarantee, so should to further strengthen the construction.

Keywords - Occupation education, petty officer academy, vocational education

\section{地方职业教育院校对士官院校教育转型的启示}

\author{
付明海 ${ }^{1}$, 赵艳辉 ${ }^{2}$ \\ 1) 蚌埠汽车士官学校, 蚌埠, 安徽, 中国 \\ 2) 蛙埠汽车士官学校, 蛙埠, 安徽, 中国
}

\begin{abstract}
摘 要 构建适合任职教育特点的人才培养模式是士官院校教育转型的关键; 教学评价体系要以提高学员的实际部队任职能力为 本位; 师资队伍建设要立足于整合, “内引” 加 “外联”, 形成和优化 “双师” 型师资队伍; 教学实践基地是士官院校教育教学质量和 特色的保证, 要进一步加强建设。
\end{abstract}

关键词＼cjkstart职业教育，士官院校，任职教育

“他山之石, 可以攻玉”。认真分析地方职业教 育院校的调整、改革与发展, 从中吸取有益的启示, 对于加快士官院校向任职教育调整和转型具有积极 意义。

1. 抓住 “牛鼻子”——构建适合任职教育特点的人 才培养模式是向士官院校教育转型的关键

人才培养模式, 是指高等院校根据人才培养目标 和质量标准, 为教学对象设计的知识、能力和素质结 构以及怎样实现这种结构的方式。地方职业教育院校 认为, 人才培养模式和教学内容体系的改革与建设, 是关系到职业技术教育特色能否形成的关键。职业教 育人才培养模式不能沿袭普通高等教育模式。职业教 育要构建适应社会发展需要、具有鲜明特色的人才培 养模式。因此, 地方各类职业教育院校对人才培养模
式改革与建设的项目计划, 表现出极大的兴趣和热 情。如四川信息职业技术学院树立了“以赛促教”的人 才培养观, 把技能竞赛作为促进教学质量提升的重要 手段之一, 融入到学院的专业建设、课程建设等教学 内容中去, 并将竞赛成绩计入系部教学工作考核, 常 抓不解。竞赛后认真总结, 透过比赛项目汲取技能竞 赛内容和标准, 研究教育主管部门对专业教学方向和 探寻新技术的要求, 从而一方面加强对原有教学内容 和项目的改造与提炼, 使课程教学内容与实际应用紧 密结合, 另一方面将竞赛标准和技能规范纳入各专业 人才培养方案, 达到竞赛成绩和人才培养质量双丰收 的效果。

士官院校向任职教育转型, 意味着人才培养模 式、教学计划、教学目标、教材、教案、教学组织、 教学保障、后勤保障、师资队伍等等都要随之调整。 
工作千头万绪, 涉及单位和人员比较多。我们只有抓 住人才培养模式的调整和建设这个关键, 其他方面的 调整和改革都围绕着这一点进行, 才能抓住重点, 调 而有序, 起到纲举目张的效果。从地方职业教育院校 的经验来看, 士官院校人才培养模式的构建要注意以 下三个问题:

一是实施分类培养。地方职业教育院校由于生源 多样而注重依据生源特点划分不同的种类进行培养。 同样地, 军队的士官院校, 教育的对象也有许多的类 型和层次。对这些不同的教学对象和教学层次必须采 用不同的教学计划、教学大纲和教学目标, 而不能眉 目不分, 搞一锅端。

二是灵活调整学科和专业。实行任职教育以后, 学员在院校只是短暂的学习, 他们直接面临的将是部 队的任职需要。而部队的需要是不断调整和变化的。 这就要求我们根据部队的实际需要和学员的实际情 况, 灵活调整院校的学科和专业。部队需要什么专业 我们就设什么专业, 学员和任职岗位需要什么知识, 我们就设什么课程。

三是学练并重和学以致用。学练并重是任职教育 人才培养模式的一个重要特征。我们要改变过去学历 教育那种只注重专业理论教学、注重学科知识的完整 性和系统性, 而轻视实践操作的高分低能型的教育模 式。采用整合的能力观, 通过对部队的不同岗位进行 系统分析, 确定知识、能力和素质结构, 以此来设计、 开发课程, 合理安排实践教学。在教学过程中要强调 学以致用, 在院校为学员创造逼真的部队岗位环境, 使学员到部队以后能尽快适应部队不同岗位的需要。

\section{2. 定好 “方向标” ——教学评价体系要以提高学员 的实际部队任职能力为本位}

纵观近年来地方职业教育院校在教学评价体系 上的调整和改革, 可以看出, 他们十分注重学生实际 能力的提高。他们认为, 职业教育要完成教育模式的 变革, 必须改变传统学历教育教学质量监控评价体 系, 把学科本位的评价观念转向能力本位的评价观 念。他们注重克服重视层次、忽视类型、崇尚理论、 鄙视技能的思想观念, 构建基于社会层面上的, 而不 是基于教育内部层面上的人才培养立交桥。如长沙电 力职业技术学院在强化职业能力过程中, 强调实践能 力。各专业运用课程体系动态调整机制, 及时掌握专 业岗位群的职业能力要求的变化, 按照 “循序渐进, 全面覆盖” 的原则, 将实践教学纳入课程体系的整体 设置中进行整体重构优化。在课程考试中, 他们注重
实践性教学环节的考查。完成了重点建设专业各实践 性教学环节的技能标准、考核题库和网络考试题库建 设; 将技能标准有效融入到专业课程体系中, 加大校 本教材的开发力度, 实现知识、技能有机结合, 所有 实践性课程（含 “一体化” 课程）均按 “技能标准” 组织教学; 出台了《考试管理办法》、《抽考管理办 法》、《课程考核及成绩评定细则》、《课程考核与 成绩评定办法的改革意见》等一系列制度和措施, 确 保了理论考试与技能考核相结合、形成性考核与终结 性考核相结合、网络考试与传统考试相结合、统考与 抽考相结合的学生学业评价体系的顺利实施。

从地方职业教育院校调整改革的经验来看, 如果 说人才培养模式是院校向任职教育过渡的 “牛鼻子” 的话, 那么, 教学评价体系就是 “方向标”, 用好了 它就能保证我军的士官任职教育朝正确的方向发展。 士官院校要着重抓好两个方面: 一要进一步转变思想 观念, 使广大教员和教学管理人员充分认识到, 教学 评价上已经不是 “一张考卷论英雄” 的时代了。我们 要从注重对理论教学的监控评价转向对理论与实践 结合的监控评价, 突出实践教学的地位, 把学员的部 队任职能力提高作为标准。二要组织有关人员抓紧时 间建立以提高学员实际操作和部队任职能力为标准 的教学评价体系, 制定可操作执行的与任职教育教学 目标相适应的教学评价标准, 从评价体系上对士官教 育转型提供正确的方向。

\section{3. 用准 “育才人”一师资队伍建设要立足于整合, “内引” 加 “外联” , 形成和优化 “双师” 型师资队 伍}

地方职业教育院校认为, 师资队伍是完成教学任 务的骨干, 是提高教学质量的关键。我国高等专业技 术院校师资队伍存在的主要问题, 是获得硕士研究生 及更高学历的教师比例偏低; 教师的工程实践能力有 待提高; 专业和学科带头人匮乏; 教师进修和培训的 渠道不畅, 缺少系统的培训计划。针对这些问题, 他 们加快了自身师资队伍的建设步伐。主要措施有: 采 取 “内引、外训” 的方法, 采用灵活的方式, 脱产和 不脱产的、全日制和部分时间的, 以及网上学习等方 式提高教师业务素质。通过教师在外校攻读硕士学位 等措施, 提高教师学历层次。要求高职专业教师具备 “双师” 素质。为加强高职教师队伍建设, 教育部专 门出台了《关于进一步完善职业教育教师培养培训制 度的意见》（教职成[2011]16），逐步建设我国的建 
立高职教师继续教育制度, 进一步从制度上提高高职 教师的师资队伍建设。

地方职业教育院校在师资队伍上的问题在士官 院校或多或少也存在着。由学历教育向士官任职教育 转型, 需要重新建立一支既有很高的理论水平, 又能 精通部队工作的军事素质过硬的复合型教员队伍。为 此, 我们要根据任职教育的需要对教员队伍建设采取 以下三项措施:

一是立足于任职教育的实际需要, 对现有的人才 资源进行整合。现有的师资力量是进行士官教育的根 本。要根据任职教育需要, 对现有的教研室进行撤消、 合并、改编调整。提高教员实际操作能力和部队工作 能力, 由专科教员转型为复合型 “双师” 教员。

二是 “内引” 师资人才。我们要在从其他院校毕 业生中引进任职教育急需的优秀人才的基础上, 从相 关部队引进少量人才, 这部分人的部队经验丰富, 实 际操作和工作能力强, 有助于提升我军士官院校的教 育水平。同时, 对于那些士官任职教育教学急需的学 科专业拔尖人才, 可以采取设立客座教授的办法为我 所用。他们的加盟, 不仅可以开阔教员、学员的眼界, 还能促进士官院校任职教育教学和科研的快速发展。

三是通过 “外联” 提高现有队伍素质。要鼓励教 员尤其是中、青年教员到一些著名高校和任职教育院 校进修和学习, 鼓励他们到相应部队去代职, 增加部 队实践能力, 博采众长。采取联合培养的方式, 选派 教员在职攻读其他院校的研究生。

\section{4. 建好 “练兵场” ——教学实践基地是士官院校教 育教学质量和特色的保证, 要进一步加强建设}

地方高职院校认为, 加强教学实践基地建设, 是 培养合格工程技术应用型人才的必备条件之一。教学 实践基地是高职教育质量、特色的保证。用高等职业 技术教育人士的话说, “那是心脏, 是直接生产生产 力的地方”。如长沙电力职业技术学院在实践教学场 地建设过程中, 制订了新建实训场地 (基地) 和现有 实验、实训、实习场地升级改造计划。建设过程中注 重教学、培训、技能鉴定和技能竞赛等功能的融合, 将现场设备内置。建成了由 57 个实训室构成的覆盖发 电、输电、供电到用电的 “三化”（实训环境的现场 化、实训过程作业的标准化、实训基地的开放化）实 训基地和 30 个校外实习基地，构建了基本技能实训、 专项技能实训、综合技能实训、专业拓展实训、岗位
适应实训等五环节实践教学体系。形成了从课内实训 到综合实训、从基本技能实训到职业技能实训、从课 堂教学到社会实践、从专业认识实习到生产实习的多 种校内外交替专业实践教学体系, 并贯穿专业人才培 养全过程。

地方职业教育院校加强教学实践基地建设的实 践说明, 教学基地是有效培养学员实际操作应用能力 和第一任职素质的场所, 是评价高校任职教育能力标 准的一个重要方面, 是院校教学的优势之所在。有了 这些场所, 就可以有效地培养学员的实际动手应用能 力, 提高培训的效果, 使学员尽快适应部队任职岗位 的需要, 为部队输送大批合格的适应部队实际需要的 优秀人才。离开了这些场所, 就不能有效地培养学员 的实际动手能力, 就会使院校教育脱离部队的实际需 要, 就失去了任职教育的本质意义。

士官院校经过多年的不解努力, 都建成有一大批 相应的教学实践基地, 为培养部队急需人才发挥了重 要的作用。这是我们开展士官教育的优势所在, 是其 他院校不可比拟的。对此, 一方面我们要充分发挥它 们在士官任职教育方面的优势, 在教学中充分利用这 些教学实践基地, 提升我军的士官教育水平。另一方 面, 我们还要进一步加强它们的建设, 对其功能进行 进一步的调整, 使其更能进一步适应士官任职教育的 教学需要, 使我们的优势更加突出。另外, 我们还要 在相关部队建设一批教学实践基地, 加强与相关部队 的交流和沟通, 形成院校和部队紧密结合, 共同提高 士官教育教学效果的目的。

\section{参考文献(References)}

[1] Youhua Huang. Occupation Education Reform and Innovation. Publishing House of Electronics Industry. 2009 years.

[2] Weidong Lu, Yuecai Xu, Xingyin Li. On the Characteristics of Education Officer College Interpretation of. Chinese Military Education, 2011 (6) 56-58.

[3] Liujing Zhong, Yanhui Wang. Teachers Professional Development Office on Military Academy. Research on University Teachers Chinese, 2009, (4).

[4] Zhiting Zhu. Modern Education Technology into Information Technology Education. Beijing: Higher Education Press, 2011.89-99. 